\title{
THE EXPANSION OF URBAN ESTATE PROJECTS IN THE AREA SOUTHEAST TERESINA -PI
}

\author{
Lineu Aparecido Paz e Silva
}

p. $51-63$

\section{revista}

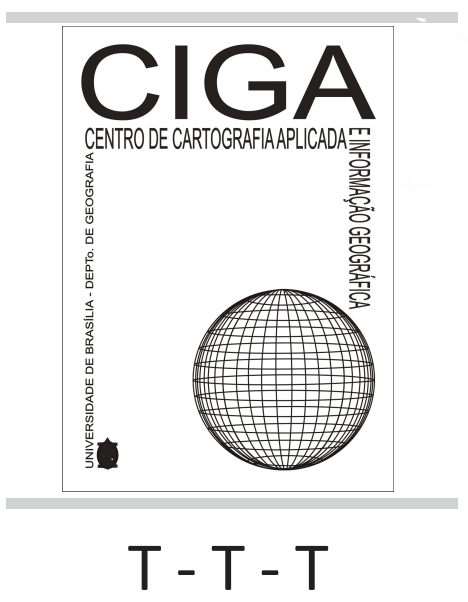

Revista Eletrônica: Tempo -

Técnica - Território,

V.5, N.1 (2014), 51:63

ISSN: 2177-4366

DOI: https://

doi.org/10.26512/

ciga.v5i1.22177
Como citar este ar tigo:

SILVA, L. A. P. THE EXPANSION OF URBAN ESTATE PROJECTS IN THE AREA OF SOUTHEAST TERESINA -PI Lineu Aparecido Paz e Silva. Eletronic Magazine: Time - Techinique - Territorry, v5, n.1 (2014), p. 51:63 ISSN: 2177-4366.

DOI: https://doi.org/10.26512/ciga.v5i1.22177

Available in: http://periodicos.unb.br/index.php/ciga/

Este obra está licenciado com uma Licença Crea tive Commons Atribuição-NãoComer cial 4.0 Inter nacional. 


\title{
THE EXPANSION OF URBAN ESTATE PROJECTS IN THE AREA OF SOUTHEAST TERESINA -PI
}

\author{
Lineu Aparecido Paz e Silva \\ Licenciado em Geografia Pela Universidade Estadual do Piauí-UESPI \\ Mestrando em Geografia pela Universidade Federal do Piauí-UFPI \\ Professor de Geografia da educação básica \\ lineuprofgeo@hotmail.com
}

\begin{abstract}
Urban space is the one built by man , not the natural environment . The set of land uses that have joint organized and evenly, being set based on the interests of the promoters of urban space , which are the owners of the means of production, land owners, property developers, the state and excluded social groups, and this work has emphasized the role of property developers who work for the reproduction of capital and the state that also modifies the space of the city and often acts as a real estate developer financing ventures , acting in this way together with promoters estate. These agents resize the space of the city , such as the study area that early in his employment had been the main agent with the construction of numerous housing estates, and now the action of developers is better perceived , since there are many condominiums that have been or are being built in the region . So the work is to analyze the contributions of these developments for urban expansion area south of Teresina -PI , as well as the motivations that led the developers to invest in this area and their strategies for success these condos .
\end{abstract}

Keywords : urban space . Real Estate Developers . Real Estate Developments . Urban sprawl. Southeast Zone . Teresina -PI .

RESUMO: O espaço urbano é aquele construído pelo homem, não mais o meio natural. É o conjunto de usos do solo que possuem articulação de maneira organizada e homogênea, sendo configurado a partir dos interesses dos agentes promotores do espaço urbano, que são os proprietários dos meios de produção, os proprietários fundiários, os promotores imobiliários, o Estado e os grupos sociais excluídos, sendo que este trabalho enfatizou a atuação dos promotores imobiliários que trabalham para a reprodução do capital e a do Estado que também modifica o espaço da cidade e por muitas vezes atua como promotor imobiliário financiando empreendimentos, atuando dessa maneira em conjunto com os promotores imobiliários. Esses agentes redimensionam o espaço da cidade, como por exemplo, a área estudada que no inicio de sua ocupação teve o estado como principal agente com a construção de inúmeros conjuntos habitacionais, e atualmente a ação dos promotores imobiliários é melhor percebida, visto que são muitos condomínios que foram ou estão sendo construídos na região. Assim o trabalho se propõe analisar as contribuições destes empreendimentos para a expansão urbana da zona sudeste de Teresina-PI, assim como as motivações que levaram os promotores imobiliários a investir nessa área e suas estratégias para o sucesso desses condomínios.

Palavras-Chave: Espaço urbano. Promotores Imobiliários. Empreendimentos Imobiliários. Expansão urbana. Zona Sudeste. Teresina-PI. 
RÉSUMÉ: L'espace urbain est celui construit par l'homme, pas l'environnement naturel . L'ensemble des utilisations des terres qui ont organisé conjointement et régulièrement , être ensemble sur la base des intérêts des promoteurs de l'espace urbain , qui sont les propriétaires des moyens de production, les propriétaires fonciers, les promoteurs immobiliers, l'état et exclus les groupes sociaux , et ce travail a mis l'accent sur le rôle des promoteurs immobiliers qui travaillent pour la reproduction du capital et de l'Etat qui modifie aussi l'espace de la ville et constitue souvent un financement de développeur immobilier entreprises, agissant de cette façon avec les promoteurs immobilier . Ces agents redimensionner l'espace de la ville , tels que la zone d'étude qu'au début de son emploi avait été l'agent principal de la construction de nombreux lotissements, et maintenant l'action de développeurs est mieux perçu , car il ya beaucoup condominiums qui ont été ou sont en cours de construction dans la région . Donc, le travail est d'analyser les contributions de ces développements pour la zone d'expansion urbaine au sud de Teresina -PI , ainsi que les motivations qui ont conduit les développeurs à investir dans ce domaine et leurs stratégies pour réussir ces condos .

Mots-clés : l'espace urbain . Immobilier Développeurs Estate. Développements immobiliers . L'étalement urbain . Zone sud-est. Teresina -PI .

\section{INTRODUCTION}

The city is organized from the activities of promoters of urban space as the owners of the means of production, land owners, property developers, state and excluded social groups that transform the urban environment primarily considering their interests . This action can change from one place to another and also from time to time , as one of those actors can influence more directly in a space. In the city of Teresina, being an urbanized area , it is possible to analyze this process, with extensive modification of the urban area since the 1950s in various sectors such as economic, social , noting major expansion of the city in regards to your space with foundation new neighborhoods .

The southeastern area of Teresina began their occupation in the 1970s, through the intervention of the State with housing facilities to house people living in lower income areas as a center, as well as people who were in risk areas of the capital, with that this area currently has about 133,008 inhabitants, according to Census of the Brazilian Institute of Geography and Statistics - IBGE 2007 , formed by clusters of 17 neighborhoods , and slums , Parks and Boarding, and according to the land use city of Teresina is divided into commercial and residential areas in this priority, and a special area , industrial and service apesentando one dynamics in various sectors, especially in the commercial.

In this part of town the construction of condominiums increased significantly . Are condominiums as Lenita Ferreira , Margins Poty , Grand Park Dirceu , Condo Chapada do Corisco , Residential Gardens Club , American Club Residence , Colorado , Mirafloris , 
Heliopolis among others, demonstrating the great attraction that has become this part of Teresina, and the worked aimed to analyze the contribution of these real estate projects in the urban sprawl of the capital of this region, primarily considering its historical , socioeconomic, actions of agents producing space and the transformation they are causing in the region , discovering its action strategies and reasons for change condos for that area of the city , in addition to understanding how urban space is formed more generalized way .

The research that has a phenomenological approach , since the intention is to explain facts that are presented , aiming to understand the subject from the environment in which it is inserted , considering consciousness and how phenomena are shown to her , and their choices that make up essence demonstrating what it truly is seeks to analyze the phenomena in themselves and their significance in our consciousness that in turn happens to absolutely essential and objective approaches sheltering structures, and even qualitative, since the understanding of the site was taken in its entirety directly on objects study, the researcher being the primary means to describe this instrument means the intention to solve the problems established, considered the opinions of the author under an inductive approach .

To achieve the goals mentioned above work included literature reviews of books and papers in general that helped in the understanding of the phenomenon in question, with analyzes of space and producers of the same agents, with emphasis on the role of the state and property developers are important elements in the dynamics of urban space, as previous studies addressing the issue of urban sprawl and real estate and research in electronic addresses of the enterprises themselves, in addition to builders, developers and real estate . And for better knowledge of the real estate and construction projects already marketed in the study area were visited, and photographic recording of these works .

Still important establishments that contribute to the dynamics of the area were photographed in order to enhance the vision of the region's economy , such as supermarkets , department stores , community gardens , clinics , hospitals , and banks. The research found all the developments that are being built in the area , as well as the already occupied , and condos that are still in the process to launch , noting that occupied large green areas in addition to observing that are scattered throughout the southeast area of the capital .

\section{EXPANSION OF URBAN ESTATE PROJECTS IN THE AREA OF SOUTHEAST TERESINA - PI}

The transformations which passed the city are decisive for the conditions that present themselves within the urban space. These conditions relate to the differences between social

Eletronic Magazine: Time - Techinique - Territorry, V.5, N.1 (2014), 51:63 ISSN: 2177-4366 
classes and how to produce established for the construction of that space, which in turn is reflected in society and in their way of relating to the urban environment . So , what can be seen in the city space is a result of social relations in conjunction with the space in a complex and dynamic process that is influenced greatly by the actions of agents producing urban space.

Agents have their action towards the urban space by modifying the process of production and reproduction of city space, which often does not happen in a way that benefits the general population , since the person who has working capital to keep it . At this juncture the action of developers will be prioritized in the study area , since their performance is currently cause for questioning when the construction of gated communities is notable expansion of capital in this region. Is important to mention that these agents interfere with the production of space in this area not only process, but in the other capital Teresina .

This urban expansion in the southeastern area is still a result of grounds relating to capital that needs constant reproduction, such as real estate and capital works to reach these results to search for new areas to establish new enterprises creating new demand, is something inherent in this activity, since these agents aim at maximum profit . Thus the role of real estate developers in the study area is aimed at the production of urban space for the reproduction of capital , transforming the space into a commodity .

These developments are located along the entire length of the south-east ( Figure 01 ) , however, some are still under construction and still others at launch . So is visible in the proximity of some urban areas already provided with equipment such as Gran Park Dirceu , the first venture of its kind in the area , dated 2009 , in addition to the locations of future projects where he is currently a large area of vegetation as with the Mirafloris and Barra Grande Village neighborhood of condominiums .

These condos are located in an area considered the outskirts of the capital, which had initially focused their homes for the low income population, since according to the Brazilian Institute of Geography and Statistics ( IBGE ), the income of the population of the southeastern region of Teresina has the 2000 , of the 29,112 households surveyed was $35.3 \%$ with income up to a monthly minimum wage; 29 , 2 \% earned less than two minimum wages and $13.6 \%$ had an income of up to three minimum wages, showing that the population of this area lived with low incomes . Moreover, this area did not have adequate infrastructure or basic services early in their occupation. ( LIMA , 2011)

However the area had great economic growth, which certainly motivated the installation of condominiums in the area. These projects are located in various districts of the south-east of Teresina, with apartments facing the various social classes, since many of them 
rely on government support with regard to funding through the Minha Casa Minha Vida federal government thus occupy spaces that were previously large vegetations besides being side by side with large housing , villages and slums sets as in the Gardens Residence Club condo, which is located near the Renaissance one and Novo Horizonte together .

These condos with their apartments are significantly different forms of property found in this area of the city, that changing the local landscape , as shown in Figure 01 below, which realizes the large coexistence of this new development with houses found in the area . Thus this expansion is causing a significant change in urban land use, because large areas that had no type of housing are being replaced by these developments, in addition to locations close to these buildings that are also being transformed with opening and paving of roads and service establishments such as street lighting and sanitation .

These changes are part of the strategies used by developers who are allied to the State so that these areas be provided these services in order to make these spaces have a greater appreciation, which is perceived in some operations studied fact, since many received enlightenment where the streets will be built and still paving without even having no resident still in place. Thus you can see that the action of these agents is common and may also verify that the state is still active in the region, although in different fashion that started in the 1970s with the housing .

The action of developers practices must constantly be renewed to achieve your goal is profit , so they are used in many ways to enhance their activities with these developments a way to achieve this goal , since they incorporate them values a "new way of living ," seeking to harness these concepts welfare, status, in order to increase the prices of these constructions besides using these strategies to sell more properties .

These strategies are seen in many of the operations studied, where the aspect of safety and comfort are well cited in the ads and commercials aired on local television channels, including using national artists in an attempt to higher real estate values .

The quality of life is also widely used in the promotion of these ventures, for that reason they are endowed with many elements that print comfort and contact with nature , different from the way of life of neighborhoods located around these works often lack or minimal infrastructure. Thus it is common to count works with pools, playground, party , barbecue, football fields, gymnasiums, among other attractions that end salon for a distance greatly the way of life of the residents of those places with their " neighbors " .

These attractions transform these places into large objects of desire of people who have no home or to live , ie , is more than owning a home of their own , is to live with quality Eletronic Magazine: Time - Techinique - Territorry, V.5, N.1 (2014), 51:63 ISSN: 2177-4366 
, often denying what is around you . Thus it builds a new segregation , since the periphery itself, are seen completely different situations .

This form of segregation is found in other areas of the city, showing that it is a type of enterprise that was understood and accepted by the residents of the capital , and the first buildings were installed in the 1970s in the central area undergoing major expansion in decades of 1980 and 1990 , especially on the east side, resulting in major changes in the landscape of the capital, where he also realizes that the strategies of developers have also diversified, because the study area was not the object of interest of these agents .

Strategies can be further analyzed with regard to security, since these condos are set in peripheral neighborhoods considered violent, and so far these developments underscore the security apparatuses used as watchtowers security , electric fence , cameras that operate 24 hours a day , and armed guards, showing once again the separation of neighboring residents who want to achieve as shows entries condos Gran Dirceu Park , located at Rua Alexandre Gomes Chaves in Itararé neighborhood, and input Gardens Residence Club , located at Adam Medeiros Soares street, New Horizon neighborhood, still under construction .

Thus the real estate capital, according to Tavares (2010) demonstrates from these works there is a new way of life, ie living in these apartments the developers create the imagery that reside in these endeavors is "better " because it creates a image of modern buildings also emphasizing that other ways of living are old , this being more a strategy to eliminate competition . In this sense it is important to the vision of Lima (2010 , p . 176 ) " In the real estate market, innovation is used to differentiate the new product from existing housing stock and thus produce a depreciating effect on past production of property ."

It is interesting to understand how the real estate capital creates the population quota for these new homes, it is important to first understand the process of buying a property , whereas when buying a property families are consuming space, both on the property itself , as by the elements that surround it . These elements can be social , cultural or symbolic natural order.

So when purchasing a property to suit the occupant and will probably live according to the characteristics the property that has, in turn , may change over time both in the best sense of appreciation, and for loss of value or local characteristics, so it is an important decision . So the developers working in their endeavors to print values that bring innovation, differentiated services or resources to create in the minds of prospective buyers the idea of a dream come true . 
Another way to appreciate these developments that is used by developers is to appreciate the location, always emphasizing that are affordable and close to important sites, demonstrating how the place is "special " , as shown in the advertisement ( Figure 06 ) the condominium neighborhood Mirafloris, located in the Santana Mill Road .

This neighborhood condominiums will have a $201.624 \mathrm{~m}^{2}$ of built area , will feature 4,160 apartments , 64 apartments per condo , condos and 70 , as shown in Figure 07 below is therefore a major undertaking and the first capital in this model , demonstrating the large amount of land that still exists to be used in this region .

Figure 07 : Plan of condominiums Mirafloris neighborhood

The large amount of land in the southeastern region of Teresina has assisted in the expansion of these projects that is being observed in this study , since this area had large areas of vegetation , and in some it is still possible to realize this reality as shown in Figure 08 below area surrounding the condo Gardens Residence Club in Novo Horizonte neighborhood. ( TAVARES , 2010)

This transformation would be very difficult in the past, mainly because of the location of the area which was regarded as far from the downtown area , and also because it has no structure to the scale developments being built, however the area showed great dynamism, with establishments banks, supermarkets, universities, colleges, major department stores, hospitals and clinics ( Figure 09 ), resulting in interest of property developers in this area .

The reasons for these companies to establish themselves in this area of the city were surveyed by Lima (2011) to study the formation of a sub-center in the southeast of the capital , resulting in the development of a framework where you can see the number of establishments, besides the varied motivations for the choice of location for the southeast area of the company ( Table 01 ) .

Table 01 : Shops in the southeastern zone of Teresina -PI and their motivations

Establishment Motivation for establishing the company in the southeastern area

Sweet Shop Mania By turning customers

City home for being the most populous district in the capital

Commercial Carvalho Due to neighborhood development

Drugstore Big Ben On account of the development of the neighborhood

Jet Stores Ltd. For commercial development

J stores . Monte Center For the structure of the neighborhood, great neighborhood

Optical Flow Diniz people

Eletronic Magazine: Time - Techinique - Territorry, V.5, N.1 (2014), 51:63 ISSN: 2177-4366 


\author{
Ricardo Paraguassu flow of people \\ Pax Growth Union Neighborhood \\ Optical Prado By the size of the neighborhood and population \\ Source : San Francisco ( 2014 ) adapted .
}

This economic growth was also evident in the disclosure folder condo Gran Park Dirceu which highlighted the variety of companies located in the area and the evolution they had making them become reference in that space , making the real estate capital began invest in this area of the city. Thus the construction of condominiums this by resizing the area where they are established, as were hitherto characterized by dwellings to lower classes that were initially occupied by families from risk areas and low income in general, still showing a mixed forms of occupy this important area of the capital .

The developers are selective when choosing places to build new ventures, for that reason condos are usually established in areas that have connections to important streets and avenues. This warranty separation still occurs due to the value of the property , as they are often inaccessible to most of the local population and the city as a whole, thus strengthening the trend of homogeneity occurring in gated communities in this area of the capital . Thus this trend is doubly determined both by the security templates placed in these enterprises as property prices by restricting way of determining who can live in these places . In this sense it is possible to analyze from Table 01 below the average prices of these properties , in accordance with the values found in the electronic addresses of estate agents who market these ventures .

Table 01 : Charges Closed southeast area Teresina - PI

Average price of properties studied

Condo Location Average Value Entrepreneur

Lenita Ferreira Street Pr . Camilo José Son / Zone - All Saints 84,000.00 Skora Engineering

Mauro Lopes - Engineering

Condo Margins Poty Av San Francisco /

Neighborhood - Complied 123.000,00 Bethel Construction

Grand Park Dirceu Rua Alexandre Gomes keys / Zone - Itararé 135,000.00 Construction Boa Vista

Condo Chapada do Corisco Street Our Lady of the Conception / Zone - All Saints 124.000,00 Construction Claw 
Gardens Residence Club Street Adam Medeiros Soares / Neighborhood - New Horizon 138.000,00 Betacon and NPJ

American Club Residence Via East Forty- Two / Zone - All Saints 108,000.00 TME Construction

Colorado 18 / Neighborhood Street - Round 112,000.00 Construction Guarantee

Mirafloris Cecilia Alves - Neighborhood Green Cap 100,000.00 Construction Success

Heliopolis Park / Street 05 Neighborhood - Colorado 114,000.00 Construction Habplan

Condo Villa Natura Av Mirtes Melon /

Tell Gurupi 550,000.00 Engineering

Bar Grand Village Street Walter Braga / Park Poti 111.000,00 Construction Amorim Coutinho

Source : Field study

Therefore it is possible to verify the high cost of properties being built in the region in general , a condition that is not realized in this area that has relatively affordable properties , since most homes are originating from housing estates of the 1970s and shaped the space in this region, which is now being transformed by the construction of these new developments .

Another feature that is clearly perceived with analyzing this picture, beyond the amount of condos being built at the same time, there are many, is the variety of entrepreneurs who are operating in the region shows that it is an area that is being valued by many builders, developers, real estate beyond the work of architects and landscape architects who are also part of the developers. In this picture you can see the performance of large companies such as Boa Vista construction company that operates in the city for 30 years, and the construction of Success largest economic group in the state.

The condominiums built by these entrepreneurs in the southeastern zone of Teresina have many features in common, which is often seen as a plus point in these developments , which in turn is related to elements established in the condominium that facilitate everyday life , again separating residents of that habitat type of the other residents of the neighborhood, contributing to the trend of homogeneity discussed above. These characteristics are related to the attractions of these developments as gyms , swimming pools , sports facilities , a ballroom , 3D cinema, among other elements .

So people who live in these places do not need to leave their condos to perform some daily activities, reinforcing the fragmentation of urban space towards targeting the city 
these ventures end up " denying " the rest of the area in which they live. ( TAVARES , 2010) still resulting in increased differences with regard to social and economic aspects , modifying what is considered the periphery, since it acquires features of the center , ie , these ventures eventually modify relations between society, economy and territory.

The growth of this type of development also shows the appropriation of public spaces, such as condominiums hinder the free movement of persons in all areas of the city precisely because they are surrounded, demonstrating a restricted character of the use of these new public spaces that should be used by all in a democratic manner . Thus the expansion of the city happens with spaces for the community, but selectively, since only these residents will have access to these spaces .

Given this expansion discussed throughout this work, it is possible to observe a trend that continued installation of new process developments since many are still planned for the years themselves, others are still under construction and completion process, beyond those already inhabited you can still go through expansions . Thus the process of redefining that space probably will continue not only by the enterprises themselves, but with all the changes they bring with them , altering and further fragmenting the city space .

Thus further studies are still needed since it is an ongoing process that will have numerous implications in the urban area of Teresina -PI and therefore deserves greater knowledge on the part of the whole society Teresina , because many doubts and questions will still arise about this new way of living found in this area .

\section{CONCLUSION}

The southeastern region of Teresina -PI showed great social and economic growth , since its occupation in 1970 until the present moment, with great dynamism in the commercial sector establishments with several shops, banks, supermarkets , among others, which transformed this area attractive to real estate , one of the leading producers agents of urban space, beyond the state that acts in conjunction with these social actors, with the funding of many properties .

Was considered to understand the reality found in the southeastern part of the city with the expansion of urban space and condominiums his training with the action of the various promoters of space, that produce this environment according to their interests , prioritizing the actions of the state and property developers , the main agents that changed and still change this area of the capital, the process of urban expansion of the city considering social and economic aspects to analyze a broader and better understanding of the motivations 
that led to the implementation of these condos in the area and the consequences of your property.

These condos are redefining the space in this area of the capital a process that is under way and that possibly will be continued, as many projects are still planned, since it is a form of housing Teresina well accepted by the population as well as still have many spaces where these ventures can be installed with many green areas present in the capital .

Thus these developments are creating and will even create a new socio-spatial reality , which can be proven through the landscape where the condos are installed already living with dwellings of housing projects in the area , besides the transformation resulting from the replacement of old green areas for these condominiums that are modified even before the start of construction for these projects, with openings of streets, street lighting and sanitation.

This reality also implies fragmentation of urban space, since the condos are built with numerous safety equipment to ensure that proximity is only physical , it is the people who choose to live in these condos mostly seek relationships only with people who are the same social class, checking with this reality a tendency to homogenization and lack of solidarity among the residents.

To conclude, the contribution of these projects to urban sprawl is evident not only by the materiality of the project, but all the elements that are necessary for its implementation and also because it provokes dynamics, yet is an expansion that eventually segregate , causing the proximity to this new way of living is just physics in a completely different reality historically found in the region .

\section{REFERENCES}

BARCELLOS , T. M. ; Mammarella , R. The Meaning of Closed Charges in Case of Spatial Segregation in the Metropolis . Department of Planning and Management . Porto Alegre, RS , 2007. P. 22 . Available at: http://www.fee.tche.br/sitefee/download/tds/019.pdf . Access on Feb 20 . 2014.

BORTOLO , C. A. . Production of a Public Space and The Producers Agents City : the case of Lake Igapó in Londrina - PR . Available at: http://www.epublicacoes.uerj.br/index.php/geouerj/article/viewFile/1488/1246 . Access in Feb 21. 2014.

BEAUJEU - GARNIER , Jacqueline . Urban Geography . 2 ed . Lisbon: Calouste Gulbenkian Foundation , $1997252 \mathrm{p}$. .

CARLOS , Ana Fani Alessandri . The City . Sao Paulo : CONTEXT , 200398 p . .

Eletronic Magazine: Time - Techinique - Territorry, V.5, N.1 (2014), 51:63 ISSN: 2177-4366 
Castells , Manuel . The Urban Question . 4 . Ed . New York: Continuum , 2009590 p . . CORREA, Roberto Lobato . The Urban Area. 4th ed. Sao Paulo : Attica, 199994 p . .

Achievement, Antonio C. Teresina urban evolution : past, present and .... Charter CEPRO , v. 22 , n.1 , p.59- 69 , 2003.

HARVEY , David . The Social Justice and the City . Sao Paulo : Hucitec , 1980 291p . .

Lefebvre , Henri . The Production of Space . Trad . Doralice Barros Pereira Martins and Sergio ( the original : La production de l' espace 4 ed Paris : . . Éditions Anthropos , 2001.

LIMA , P. G. de H. . The occurrence of polycentricity in Teresina - PI : the formation of a sub-center in the Southeast. ( Thesis ) Ph.D. in Geography - Universidade Estadual Paulista " Julio de Mesquita Filho ". Sao Paulo . 2011. 204 p .

MOTA , A. A. ; MENDES , CM Considerations on strategies and actions of real estate developers in the production of urban space . Society \& Nature , Uberlândia , p . 123-130 , mar. 2006.

SILVA , A. C. of . 12 color photographs . digital , Teresina , 2014.

SOUSA , D. M. A. 1 color photograph. Digital , Teresina , 2014.

SOUSA , R ; PINE , L. et . al. Analysis of southeastern urban area of Teresina . Available at: http://porteiradocuia.blogspot.com.br/2011/03/analise-urbana-da-zona-sudeste-de.html Access on Feb 20 . 2014.

Sposito , MEB Capitalism and Urbanization - . Collection Rethinking Geography . 10 . Ed . Sao Paulo : Context, 2000.

TAVARES , M. A. ; COSTA , A. the A. . Urban dynamics and condominiums closed in Natal . GeoTextos . v. . 6 , n . 2 , p. 83-113, mar. 2010. 